\title{
HUBUNGAN INDEKS MASSA TUBUH, MASSA LEMAK TUBUH, ASUPAN KALSIUM, AKTIVITAS FISIK DAN KEPADATAN TULANG PADA WANITA DEWASA MUDA
}

\author{
Arofani Hermastuti, Muflihah Isnawati") \\ Program Studi Ilmu Gizi Fakultas Kedokteran Universitas Diponegoro \\ Jl.Dr.Sutomo No.14, Semarang, Telp (024) 8453708, Email : gizifk@ undip.ac.id
}

\begin{abstract}
Background: Low bone density can be caused by low BMI, body fat mass, calcium intake and physical activity. In young adults, low bone density increase the risk of osteoporosis. However, a recent study claimed the risk of osteoporosis is increased in obesity.

Objective: The aim of the study is to determine relationship BMI, body fat mass, calcium intake, physical activity and bone density in young adult women.

Methods: Research held on campus of Nutrition Department of Medical Faculty UNDIP Semarang in May 2012, is an observational study with cross-sectional design. Subject were 38 young adult women, aged between 18-23 years. Body weight and body fat mass was measured using Bioelectrical Impedance Analyzer (BIA), height using mikrotoise, data of calcium intake were collected with FFQ questionnaire, physical activity with an International Physical Activity Questionnaire, and bone density on calcaneus were measured using an ultrasound bone densitometry. The data was analyzed with Shapiro-Wilk, Pearson product moment and rank-Spearman correlation. Result: Most of subjects (60,5\%) are in normal bone density and 39,5\% are osteopeni. Moreover, 55,3\% of subjects are normal BMI, 63,2\% are normal body fat mass, 71,1\% are moderate physical activity, and 63,2\% have calcium intake less than nutritional adequacy. There are relationships between calcium intake and bone density ( $r=0,351$; $p<0,05)$. In contrast, there were no relationships between BMI, body fat mass, and physical activity with bone density in young adult women ( $p>0,05)$.

Conclusion: Calcium intake are related to bone density in young adult women.
\end{abstract}

Keywords: bone density; body mass index; body fat mass; calcium intake; physical activity; young adult women

\begin{abstract}
ABSTRAK
Latar Belakang: Kepadatan tulang rendah dapat disebabkan IMT, massa lemak tubuh, asupan kalsium, dan aktivitas fisik yang rendah. Pada dewasa muda, kepadatan tulang rendah akan meningkatkan risiko osteoporosis. Namun, penelitian terbaru menyatakan risiko osteoporosis meningkat pada obesitas.

Tujuan: Mengetahui hubungan IMT, massa lemak tubuh, asupan kalsium, aktivitas fisik dan kepadatan tulang pada wanita dewasa muda.

Metode: Penelitian dilaksanakan di kampus Program Studi Ilmu Gizi Fakultas Kedokteran UNDIP Semarang pada bulan Mei 2012, merupakan penelitian observasional dengan desain cross-sectional. Subjek adalah 38 wanita dewasa muda berusia 18-23 tahun. Pengukuran berat badan dan persentase massa lemak tubuh menggunakan Bioelectrical Impedance Analyzer (BIA), tinggi badan dengan mikrotoise, asupan kalsium melalui kuesioner FFQ, tingkat aktivitas fisik melalui kuesioner International Physical Activity Questionnaire, dan kepadatan tulang pada calcaneus diukur menggunakan densitometer ultrasound. Analisis data dengan Shapiro-Wilk, korelasi Pearson product moment dan korelasi rank-Spearman.

Hasil: Sebagian besar subyek (60,5\%) memiliki kepadatan tulang kategori normal dan 39,5\% osteopeni. Sebanyak 55,3\% subyek memiliki IMT normal, 63,2\% memiliki massa lemak tubuh normal, 71,1\% memiliki tingkat aktivitas fisik kategori sedang, dan 63,2\% memiliki asupan kalsium kurang dari AKG. Asupan kalsium memiliki hubungan yang bermakna dengan kepadatan tulang $(r=0,351 ; p<0,05)$. Namun, IMT, massa lemak tubuh dan aktivitas fisik tidak memiliki hubungan yang bermakna $(p>0,05)$ dengan kepadatan tulang pada wanita dewasa muda.

Kesimpulan: asupan kalsium berhubungan dengan kepadatan tulang pada wanita dewasa muda.
\end{abstract}

Kata Kunci : kepadatan tulang; indeks massa tubuh; massa lemak tubuh; asupan kalsium; aktivitas fisik; wanita dewasa muda

\section{PENDAHULUAN}

Osteoporosis merupakan penyakit tulang sistemik yang menyebabkan tulang menjadi rapuh dan mudah patah. ${ }^{1-3}$ International Osteoporosis
Foundation (IOF) memperkirakan osteoporosis akan dialami 200 juta orang di seluruh dunia pada tahun 2040. ${ }^{4}$ Osteoporosis dapat terjadi pada pria maupun wanita, tetapi wanita enam kali lebih

${ }^{*}$ Penulis Penanggungjawab 
berisiko daripada pria. $^{5}$ Osteoporosis mengharuskan pasien menjalani berbagai tindakan medis dengan biaya mahal. ${ }^{6}$

Osteoporosis merupakan salah satu masalah kesehatan yang sering ditemui pada usia lanjut. Peningkatan usia harapan hidup yang saat ini terjadi di Indonesia menjadikan pemerintah menetapkan osteoporosis sebagai prioritas masalah kesehatan yang harus dituntaskan. PEROSI menyebutkan bahwa hingga tahun 2008 di Indonesia terdapat $90 \%$ wanita dewasa mengalami osteopeni. ${ }^{5}$ Jawa Tengah merupakan provinsi dengan prevalensi osteoporosis tertinggi kedua di Indonesia, yakni sebesar 24,02\%. ${ }^{7}$ Sekitar $60 \%$ risiko osteoporosis ditentukan oleh kepadatan tulang yang dicapai pada usia dewasa muda. ${ }^{8}$ Sehingga, penting untuk memaksimalkan kepadatan tulang pada usia dewasa muda. ${ }^{9,10}$

Kepadatan tulang dipengaruhi oleh faktor yang tidak dapat diubah maupun faktor yang dapat diubah. Faktor yang tidak dapat diubah antara lain genetik (keturunan, ras, dan hormon), jenis kelamin, dan usia. Faktor yang dapat diubah antara lain adalah berat badan, asupan zat gizi, dan aktivitas fisik. ${ }^{1,3,9}$

Berat badan berhubungan secara langsung dengan kepadatan tulang. Kesesuaian berat badan wanita dewasa dinyatakan dalam rasio berat badan per tinggi badan atau disebut Indeks Massa Tubuh/ IMT. ${ }^{11}$ Teori yang selama ini berkembang, peningkatan berat badan dan IMT berhubungan positif dengan kepadatan tulang. Hubungan positif ini berkaitan dengan peningkatan massa tubuh yang memicu tekanan mekanik tulang, meningkatkan aktivitas osteoblas, sehingga meningkatkan kepadatan massa tulang. ${ }^{2-14}$ Penelitian pada anak-anak, remaja, wanita dewasa, pre dan post menopause menyatakan bahwa risiko osteoporosis yang rendah dimiliki subyek yang obesitas. Sebaliknya, subyek underweight memiliki risiko tinggi. ${ }^{14-20}$

Kesesuaian berat badan yang diukur dengan IMT tidak dapat dibedakan karena peningkatan massa lemak atau massa bebas lemak. $^{10}$ Bertentangan dengan penelitian sebelumnya, penelitian terbaru menyatakan bahwa bahwa berat badan lebih karena massa lemak justru meningkatkan risiko osteoporosis, osteopenia dan patah tulang. ${ }^{21-23}$

Pada saat ini di Indonesia mengalami double burden yakni keadaan underweight muncul bersama keadaan obesitas. Pada populasi usia 15 tahun keatas penduduk Indonesia tahun 2007, sebanyak $15 \%$ underweight (IMT $<18,5 \mathrm{Kg} / \mathrm{m}^{2}$ ),
$19 \%$ overweight dan obesitas (IMT $25-27 \mathrm{Kg} / \mathrm{m}^{2}$ dan IMT $\left.>27 \mathrm{Kg} / \mathrm{m}^{2}\right) .{ }^{24}$ Terkait fenomena tersebut, peneliti tertarik mengetahui hubungan antara IMT dan massa lemak tubuh dengan kepadatan tulang.

Asupan kalsium dan aktivitas fisik juga berpengaruh terhadap kepadatan tulang secara langsung. ${ }^{1,3,8}$ Berdasarkan survei, rata-rata asupan kalsium orang Asia usia dewasa sebesar 450 $\mathrm{mg} /$ hari. $^{5}$ Angka ini masih tergolong rendah jika dibandingkan dengan Angka Kecukupan Gizi (AKG) penduduk Indonesia usia dewasa. Berdasarkan survei RISKESDAS tahun 2007 diketahui jika 48,2\% penduduk Indonesia usia 10 tahun ke atas memiliki aktivitas fisik kurang. ${ }^{25}$

Tujuan dari penelitian ini untuk mengetahui hubungan IMT, massa lemak tubuh, asupan kalsium, aktivitas fisik dan kepadatan tulang, dengan harapan agar wanita dewasa muda dapat memaksimalkan kesehatan tulang.

\section{METODA}

Penelitian ini dilaksanakan di kampus Program Studi Ilmu Gizi Fakultas Kedokteran UNDIP Semarang pada bulan Mei 2012. Penelitian ini termasuk dalam ruang lingkup gizi masyarakat dan merupakan penelitian observasional dengan menggunakan desain cross-sectional.

Populasi terjangkau adalah wanita usia 1823 tahun yang memiliki aktivitas keseharian di area kampus Program Studi Ilmu Gizi UNDIP, dan datang pada waktu dilakukan pemeriksaan kepadatan tulang. Proses perekrutan subyek dilakukan dengan menyebarkan pengumuman. Sebanyak 219 orang datang pada pemeriksaan kepadatan tulang. Kriteria inklusi untuk mendapatkan subyek penelitian antara lain: wanita usia 18-23 tahun, sudah menstruasi, tidak dalam kondisi hamil, tidak memiliki kebiasaan merokok, tidak mengkonsumsi alkohol, tidak memiliki penyakit tertentu atau menggunakan obat hormon yang mempengaruhi kepadatan tulang. Berdasarkan perhitungan besar sampel dengan $r=0,468$, jumlah sampel minimal yang diperlukan sebanyak 34 orang. Subyek terpilih sebanyak 166 orang, kemudian sampel dipilih secara simple random sampling sebanyak 38 orang.

Variabel bebas dalam penelitian ini adalah usia, indeks massa tubuh, massa lemak tubuh, asupan kalsium, dan aktivitas fisik. Variabel terikat adalah kepadatan tulang.

Indeks massa tubuh merupakan hasil perbandingan berat badan dalam kilogram dengan tinggi badan dalam meter kuadrat. IMT normal apabila nilai pengukuran berada dalam rentang 
$18,5-22,9 \mathrm{~kg} / \mathrm{m}^{2}$. Sedangkan apabila nilai pengukuran $<18,5 \mathrm{~kg} / \mathrm{m}^{2}$ disebut underweight, $23-$ $24,9 \mathrm{~kg} / \mathrm{m}^{2}$ disebut overweight, dan $\geq 25 \mathrm{~kg} / \mathrm{m}^{2}$ disebut obesitas. ${ }^{26}$

Massa lemak tubuh merupakan hasil pengukuran massa lemak tubuh menggunakan Bioelectrical Impedance Analyzer (BIA) Beurer dan dinyatakan dalam persentase massa lemak tubuh per total berat badan yang terdiri dari massa lemak, massa tubuh tanpa lemak, dan massa tulang. Persen massa lemak tubuh wanita dewasa dikatakan normal adalah 22-31\%, dikatakan underfat apabila persentase $<22 \%$, sedangkan obesitas apabila $\geq 32 \%{ }^{27}$

Asupan kalsium merupakan jumlah asupan kalsium rata-rata per hari dari konsumsi makanan dan minuman sumber kalsium dengan satuan miligram per hari dan diukur menggunakan metode formulir semi quantitative food frequency. Hasil yang diperoleh diolah menggunakan program nutrisurvey lalu dibandingkan dengan $\mathrm{AKG}$, dan dikategorikan menjadi kurang $(<80 \%$ AKG $)$, normal (80-100\% AKG), atau lebih (>100\% $\mathrm{AKG}){ }^{28}$ Untuk wanita Indonesia usia 19-29 tahun, angka kecukupan kalsium yang dianjurkan adalah sebesar $800 \mathrm{mg}$ sedangkan wanita usia 16-18 tahun sebesar $1000 \mathrm{mg}^{29}$

Aktivitas fisik diukur menggunakan International Physical Activity Questionnaire (IPAQ). Skor aktivitas fisik diperoleh berdasarkan jenis aktivitas dikalikan frekuensi dan durasi aktivitas fisik yang dilakukan subjek selama 7 hari.
Aktivitas fisik kategori sedang apabila skor aktivitas berada dalam rentang 600-2999 METmenit/minggu. ${ }^{30}$

Kepadatan tulang didefinisikan sebagai nilai pemeriksaan kepadatan tulang dinyatakan dalam $T$-score. Bagian tulang yang diukur adalah tulang calcaneus/ tumit dengan menggunakan alat densitometer ultrasound. Disebut osteoporosis apabila nilai pemeriksaan kepadatan tulang kurang dari -2,5 SD sedangkan apabila kepadatan tulang kurang dari -1 SD disebut osteopeni. ${ }^{2,3,6}$

Analisis univariat digunakan untuk mendeskripsikan data primer. Sebelum uji hipotesis, dilakukan uji normalitas data menggunakan Shapiro-Wilk. Analisis bivariat Pearson product moment digunakan untuk melihat hubungan massa lemak tubuh, asupan kalsium, dan aktivitas fisik dengan kepadatan tulang. Sedangkan hubungan antara IMT dengan kepadatan tulang digunakan uji rank Spearman karena data IMT tidak berdistribusi normal.

\section{HASIL PENELITIAN \\ Karakteristik Subyek}

Subyek penelitian ini adalah 38 orang wanita dewasa muda berusia 18-23 tahun. Subyek yang memiliki kepadatan tulang kategori normal lebih banyak $(60,5 \%)$ jika dibandingkan subyek yang memiliki kepadatan tulang kategori osteopeni $(39,5 \%)$, dan tidak ada subyek yang termasuk osteoporosis. Karakteristik subyek dapat dilihat pada tabel 1.

Tabel 1. Karakteristik Subyek Penelitian

\begin{tabular}{llcc}
\hline & & \multicolumn{2}{c}{ Frekuensi } \\
\cline { 3 - 4 } & & $\mathbf{n}$ & $\mathbf{\%}$ \\
\hline Usia (tahun) & $18-23$ & 38 & 100 \\
\hline Kategori nilai kepadatan tulang & Normal & 23 & 60,5 \\
& Osteopenia & 15 & 39,5 \\
& Jumlah & $\mathbf{3 8}$ & $\mathbf{1 0 0}$ \\
\hline
\end{tabular}

Tabel 2 menunjukkan distribusi frekuensi subyek berdasarkan IMT, massa lemak tubuh, asupan kalsium, dan tingkat aktivitas fisik.

Tabel 2. Distribusi Frekuensi Subyek Berdasarkan IMT, Massa Lemak Tubuh, Asupan Kalsium, dan Tingkat Aktivitas Fisik

\begin{tabular}{llcc}
\hline \multirow{2}{*}{ Variabel } & \multicolumn{2}{c}{ Frekuensi } \\
\cline { 3 - 4 } & & $\mathbf{n}$ & \% \\
\hline Kategori IMT & Underweight & 7 & 18,4 \\
& Normal & 21 & 55,3 \\
& Overweight & 4 & 10,5 \\
\hline
\end{tabular}




\begin{tabular}{llcc}
\hline & Obesitas & 6 & 15,8 \\
& Jumlah & $\mathbf{3 8}$ & $\mathbf{1 0 0}$ \\
\hline Kategori massa lemak tubuh & Underfat & 8 & 21,1 \\
& Normal & 24 & 63,2 \\
& Obesitas & 6 & 15,8 \\
& Jumlah & $\mathbf{3 8}$ & $\mathbf{1 0 0}$ \\
\hline Kategori asupan kalsium menurut & Kurang & 24 & 63,2 \\
AKG & & 10 & 26,3 \\
& Normal & 4 & 10,5 \\
& Lebih & $\mathbf{3 8}$ & $\mathbf{1 0 0}$ \\
\hline Kategori tingkat aktivitas fisik & Jumlah & 11 & 28.9 \\
& Ringan & 27 & 71.1 \\
& Sedang & $\mathbf{3 8}$ & $\mathbf{1 0 0}$ \\
\hline
\end{tabular}

Berdasarkan tabel 2, diketahui sebanyak $55,3 \%$ subyek memiliki IMT normal dan $63,2 \%$ subyek memiliki massa lemak tubuh kategori normal. Lebih dari separuh subyek $(63,2 \%)$ memiliki asupan kalsium kurang dari AKG.
Aktivitas sebagian besar subyek $(71,1 \%)$ tergolong aktivitas fisik kategori sedang dan hanya sebagian kecil subyek $(28,9 \%)$ yang memiliki aktivitas sedentary.

Tabel 3. Nilai Minimum, maksimum, rerata dan standar deviasi Usia, IMT, Massa Lemak Tubuh, Asupan Kalsium, Aktivitas Fisik, dan Kepadatan Tulang Subyek Penelitian

\begin{tabular}{|c|c|c|c|c|c|}
\hline Variabel & & $\mathbf{n}$ & Min & Maks & Mean \pm SD \\
\hline Usia (Th ) & & 38 & 18 & 23 & $20.36 \pm 1.10$ \\
\hline IMT $\left(\mathrm{kg} / \mathrm{m}^{2}\right)$ & & 38 & 16.46 & 39.04 & $21.57 \pm 4.26$ \\
\hline Massa lemak tubuh (\%) & & 38 & 16.30 & 42.20 & $26.20 \pm 5.72$ \\
\hline Asupan kalsium ( mg ) & & 38 & 170.00 & 1436.00 & $683.50 \pm 291.21$ \\
\hline $\begin{array}{l}\text { Aktivitas fisik } \\
\text { menit/minggu ) }\end{array}$ & MET- & 38 & 120.00 & 2388.00 & $1092.60 \pm 652.08$ \\
\hline Kepadatan tulang ( SD ) & & 38 & -2.50 & 0.80 & $-0.82 \pm 0.73$ \\
\hline
\end{tabular}

Tabel 3 menunjukkan rata-rata kepadatan tulang subyek termasuk kategori normal. Disamping itu, rata-rata IMT dan massa lemak tubuh subyek, keduanya masuk dalam kategori normal. Rata-rata aktivitas fisik subyek adalah tingkat sedang. Namun, rata-rata asupan kalsium subyek masih kurang dari AKG yakni sebesar $683,50 \mathrm{mg} /$ hari.

Tabel 4. Tabulasi Silang Antara Faktor-Faktor Risiko Osteoporosis dengan Kepadatan Tulang

\begin{tabular}{lcccc}
\hline \multirow{2}{*}{ Faktor Risiko } & \multirow{2}{*}{$\mathbf{N}$} & \multicolumn{2}{c}{ Kepadatan Tulang } \\
\cline { 3 - 4 } & & & Normal & Osteopeni \\
\hline IMT & 7 & 4 & 3 \\
Underweight & 21 & 11 & 10 \\
Normal & 4 & 4 & 0 \\
Overweight & 6 & 4 & 2 \\
$\quad$ Obesitas & $\mathbf{3 8}$ & $\mathbf{2 3}$ & $\mathbf{1 5}$ \\
Jumlah & & & 3 \\
\hline Massa Lemak Tubuh & 8 & 5 & 10 \\
$\quad$ Underfat & 24 & 14 & 2 \\
$\quad$ Normal & 6 & 4 & $\mathbf{1 5}$ \\
$\quad$ Obesitas & $\mathbf{3 8}$ & $\mathbf{2 3}$ & \\
Jumlah & & &
\end{tabular}




\begin{tabular}{cccc}
\hline Asupan Kalsium & & & \\
Kurang & 24 & 12 & 12 \\
Normal & 10 & 7 & 3 \\
Lebih & 4 & 4 & 0 \\
Jumlah & $\mathbf{3 8}$ & $\mathbf{2 3}$ & $\mathbf{1 5}$ \\
\hline Aktivitas Fisik & & & \\
Ringan & 11 & 5 & 6 \\
Sedang & 27 & 18 & 9 \\
Jumlah & $\mathbf{3 8}$ & $\mathbf{2 3}$ & $\mathbf{1 5}$ \\
\hline
\end{tabular}

Berdasarkan tabel 4, diketahui bahwa jumlah subyek yang memiliki kepadatan tulang normal dengan IMT dan massa lemak tubuh kategori normal lebih banyak. Pada subyek yang memiliki IMT overweight, semuanya $(100 \%)$ memiliki kepadatan tulang normal. Disamping itu, subyek yang memiliki asupan kalsium lebih dari AKG, semuanya $(100 \%)$ memiliki kepadatan tulang normal. Kepadatan tulang normal juga lebih banyak dimiliki subyek dengan tingkat aktivitas fisik kategori sedang.

\section{Hubungan IMT, Massa Lemak Tubuh, Asupan Kalsium, Aktivitas Fisik dan Kepadatan Tulang}

Tabel. 5 Hubungan IMT, Massa Lemak Tubuh, Asupan Kalsium, Aktivitas Fisik dan Kepadatan Tulang

\begin{tabular}{lcc}
\hline Variabel & \multicolumn{2}{c}{ Nilai BMD } \\
\cline { 2 - 3 } & r & p \\
\hline IMT $^{\text {a }}$ & 0,228 & 0,169 \\
Massa Lemak Tubuh $^{\text {b }}$ & 0,242 & 0,144 \\
Asupan Kalsium b $^{b}$ & 0,351 & 0,030 \\
Aktivitas Fisik $^{\mathrm{b}}$ & 0,273 & 0,097 \\
\hline
\end{tabular}

${ }^{a}$ uji korelasi rank Spearman

${ }^{\mathrm{b}}$ uji korelasi Pearson Product moment

Tabel 5 menunjukkan uji korelasi bivariat antara IMT, massa lemak tubuh, asupan kalsium dan aktivitas fisik dengan kepadatan tulang. Berdasarkan hasil uji korelasi, hanya asupan kalsium yang memiliki hubungan bermakna dengan kepadatan tulang $(\mathrm{p}<0,05)$. Hubungan antara asupan kalsium dengan kepadatan tulang bersifat positif dengan kekuatan korelasi yang lemah $(\mathrm{r}=0,351)$, artinya semakin tinggi asupan kalsium maka akan semakin meningkatkan kepadatan tulang wanita dewasa muda (gambar 1).

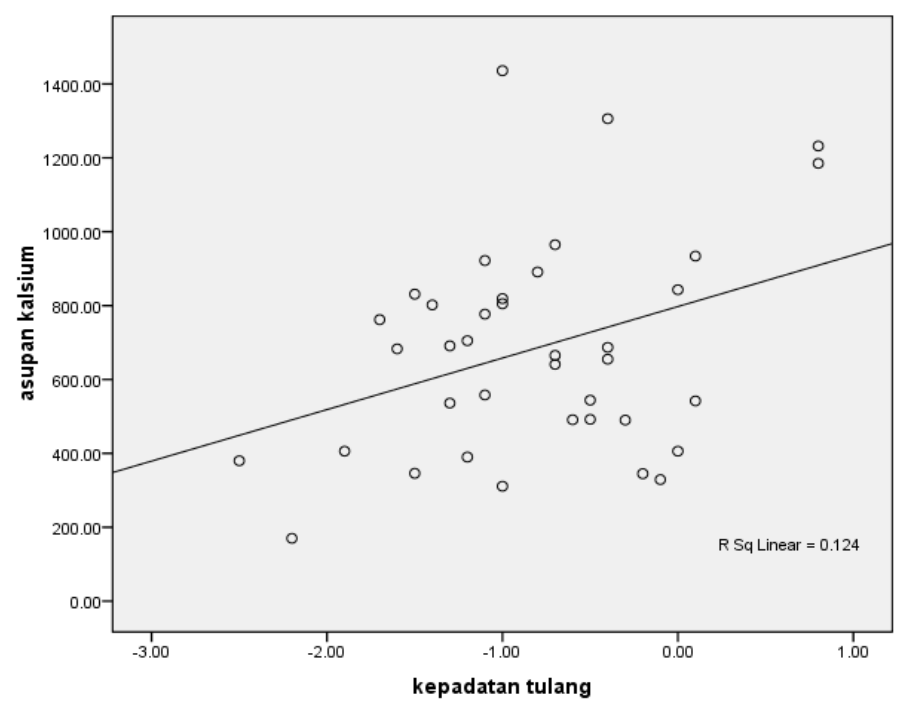

Gambar 1. Hubungan antara asupan kalsium dengan kepadatan tulang $(r=0,351 ; p=0,030)$ 


\section{PEMBAHASAN}

Subyek penelitian ini adalah wanita dewasa muda berusia 18-23 tahun dan merupakan wanita ras Asia yang memiliki risiko tinggi mengalami osteoporosis. Pada wanita, pembentukan tulang untuk mencapai kematangan tinggi badan berakhir pada usia 18 tahun, tetapi jaringan tulang masih terus bertambah hingga tercapai kepadatan tulang atau puncak massa tulang pada usia 25-35 tahun. Faktor keturunan berperan kurang lebih $80 \%$ pada pencapaian puncak massa tulang. ${ }^{2,9}$

Sebagian besar subyek penelitian ini memiliki nilai kepadatan tulang kategori normal dan tidak ada subyek yang termasuk osteoporosis. Hal ini dikarenakan wanita usia dewasa muda masih mengalami fase pembentukan tulang yang lebih besar daripada fase pembongkaran tulang. Kepadatan tulang pria dan wanita mulai berkurang secara bertahap ketika memasuki usia 40 tahun. Usia merupakan salah satu faktor risiko osteoporosis yang tidak dapat diubah, meningkat 1,4-1,8 kali setiap 1 dekade. Kemudian, setelah usia 50 tahun atau ketika menopause wanita mengalami peningkatan laju pengeroposan tulang. Penurunan kepadatan tulang tersebut akibat perubahan hormon yang mengatur remodeling tulang. ${ }^{3,9}$

Terdapat 39,5\% subyek dalam penelitian ini memiliki kepadatan tulang kategori osteopenia. Kepadatan tulang yang rendah/ kondisi osteopeni pada usia dewasa muda akan meningkatkan risiko osteoporosis di kemudian hari. Asupan kalsium yang adekuat, IMT, massa lemak tubuh, dan aktifitas fisik berperan dalam memaksimalkan kepadatan tulang dan mencegah terjadinya osteoporosis. ${ }^{1-3,9}$

Hasil uji korelasi penelitian ini, tidak menunjukkan adanya hubungan yang bermakna antara IMT, massa lemak tubuh, dan aktifitas fisik dengan kepadatan tulang pada wanita dewasa muda. Penelitian yang pernah dilakukan pada wanita pre dan post menopause menyatakan bahwa IMT dan massa lemak tubuh memiliki hubungan positif yang bermakna dengan kepadatan tulang, sedangkan massa bebas lemak memiliki hubungan negatif. ${ }^{18-20}$ Berdasarkan hasil penelitian tersebut ada dugaan bahwa, jika massa lemak tubuh lebih dominan sebagai penyusun berat badan akan memberikan efek positif pada kepadatan tulang.

Massa lemak tubuh merupakan sumber esterogen endogenous setelah menopause. Esterogen merupakan regulator pertumbuhan dan homeostasis kalsium untuk mencegah osteoporosis. Wanita setelah usia 50 tahun mengalami defisiensi esterogen karena menopause, sehingga peningkatan massa lemak menjadi penting untuk mempertahankan kepadatan tulang. ${ }^{3,9,31}$

Berbeda dengan subyek penelitian sebelumnya yakni wanita pre dan post menopause, subyek dalam penelitian ini merupakan wanita dewasa muda dan tidak menopause. Beberapa penelitian menunjukkan adanya hubungan hubungan positif yang bermakna antara IMT dengan kepadatan tulang pada anak-anak, remaja, dan wanita dewasa. ${ }^{14-17}$ Penelitian pada wanita dewasa muda menyatakan bahwa, baik massa lemak tubuh maupun massa bebas lemak berpengaruh positif dengan kepadatan tulang. ${ }^{32}$ Peningkatan massa tubuh akibat peningkatan komposisi tubuh ini akan memicu tekanan mekanik tulang, meningkatkan aktivitas osteoblas, sehingga meningkatkan kepadatan massa tulang. ${ }^{12-14}$

Hasil penelitian yang bertentangan dengan teori sebelumnya, menyatakan bahwa berat badan berlebih dikarenakan massa lemak tubuh akan memiliki hubungan negatif terhadap kepadatan tulang baik pada remaja perempuan maupun wanita pre dan post menopause. ${ }^{21-23}$ Adanya hubungan negatif antara massa lemak tubuh dengan kepadatan tulang pada remaja dan wanita dewasa muda dapat bias oleh massa bebas lemak yang memiliki hubungan positif lebih kuat dengan kepadatan tulang. ${ }^{32}$ Peningkatan massa bebas lemak terkait dengan massa otot yang lebih besar dan meningkatkan tekanan mekanik pada tulang. ${ }^{22}$ Penelitian ini tidak mengukur massa bebas lemak, hal ini dapat dijadikan rujukan untuk penelitian selanjutnya. Penelitian lain menyatakan bahwa, massa lemak berlebih pada wanita dewasa, pre dan post menopause menandakan kurangnya aktifitas fisik dan kualitas asupan zat gizi yang rendah, seperti asupan kalsium. ${ }^{33,34}$

Penelitian yang dilakukan pada wanita usia remaja, perimenopause dan lansia menyatakan bahwa massa lemak tubuh yang membentuk IMT antara $<22-24 \quad \mathrm{~kg} / \mathrm{m}^{2}$ meningkatkan risiko osteoporosis, sedangkan massa lemak tubuh yang membentuk IMT $26-28 \mathrm{~kg} / \mathrm{m}^{2}$ tidak menurunkan risiko osteoporosis. ${ }^{14}$ Kondisi ini turut dipengaruhi oleh asupan zat gizi (terutama asupan kalsium yang adekuat) dan kebiasaan beraktivitas fisik.

Hasil uji korelasi menunjukkan bahwa asupan kalsium memiliki hubungan positif yang bermakna dengan kepadatan tulang pada wanita 
dewasa muda. Pada tabel 3 diketahui bahwa subyek yang memiliki asupan kalsium kurang dari AKG, 50\%-nya mengalami osteopeni. Subyek yang memiliki asupan kalsium normal (80\%-100\% AKG), 30\%-nya mengalami osteopeni, sedangkan subyek yang memiliki asupan kalsium lebih dari AKG (1185-1436 mg), 100\% memiliki kepadatan tulang normal. Hasil penelitian ini sejalan dengan penelitian yang dilakukan pada subyek remaja, wanita dewasa, pasca menopause dan post menopause, yang menyebutkan semakin tinggi asupan kalsium akan meningkatkan kepadatan tulang. ${ }^{35-37}$ Namun, konsumsi kalsium tidak boleh melebihi $2500 \mathrm{mg}$ sehari. Selain dapat mengakibatkan konstipasi, kelebihan kalsium dapat menimbulkan gangguan ginjal (batu ginjal). Kelebihan kalsium dapat terjadi bila menggunakan suplemen kalsium berupa tablet atau bentuk lain. ${ }^{38}$ Asupan kalsium subyek yang diukur menggunakan kusioner semi quantitative food frequency tidak terlepas dari bias pengisian kuesioner. Pengisian kuesioner dilakukan sendiri oleh responden, tetapi sebelumnya enumerator telah memberikan penjelasan pengisian untuk memperkecil bias subyektifitas responden dalam memahami isi kuesioner. Bias pengisian kuesioner FFQ dapat dikarenakan daya ingat sampel dalam mengisikan frekuensi dan kuantitas bahan makanan dan minuman yang tertera pada kuesioner. ${ }^{31}$

Aktivitas fisik tidak menunjukkan hubungan yang bermakna dengan kepadatan tulang pada wanita usia dewasa muda. Penelitian lain pada wanita dewasa muda menyatakan bahwa terdapat hubungan positif antara aktivitas fisik dengan kepadatan tulang wanita dewasa muda. ${ }^{16,17,35-37}$ Tingkat aktivitas fisik dalam penelitian ini dinilai menggunakan kuesioner aktivitas fisik yang diisi sendiri oleh responden. Kemungkinan bias masih dapat terjadi karena subyektifitas responden dalam mengisikan jenis, durasi dan frekuensi aktivitas fisik. Selain itu, kuesioner yang mengukur aktivitas fisik responden selama 7 hari terakhir ini, belum tentu dapat menggambarkan aktivitas fisik dalam jangka waktu lama.

Salah satu kekurangan penelitian ini adalah letak tulang yang digunakan sebagai tempat pengukuran kepadatan tulang. Pada penelitian ini, pengukuran kepadatan tulang dilakukan pada tulang calcaneus yang didominasi $75-90 \%$ tulang trabekular. Jaringan tulang trabekular ini dipilih karena lebih responsif terhadap usia, penyakit, dan pengobatan yang mempengaruhi perubahan tulang, sehingga titik ini banyak digunakan untuk menilai risiko osteoporosis dan pengeroposan tulang. ${ }^{39-40}$ Namun, penelitian lain menyatakan bahwa adanya hubungan antara IMT, massa lemak, dan aktivitas fisik dengan kepadatan tulang ditemukan pada femoral neck dan area tulang yang didominasi oleh tulang kortikal. ${ }^{23,41}$ Rujukan bagi penelitian selanjutnya untuk menggunakan Dual-energy $X$ ray absorptiometry/ DEXA karena DEXA dapat mengukur kuantitas tulang diberbagai titik tubuh. ${ }^{3}$

\section{KETERBATASAN PENELITIAN}

Penelitian ini memiliki beberapa keterbatasan antara lain:

1. Tidak mengukur massa bebas lemak sebagai variabel bebas.

2. Penggunaan densitometer ultrasound tidak dapat mengukur kepadatan tulang pada femoral neck dan area yang banyak mengandung tulang kortikal.

3. Bias dapat terjadi pada pengisian kuesioner FFQ dan kuesioner aktivitas fisik.

4. Subyek penelitian ini hanya wanita dewasa muda ras Asia.

\section{SIMPULAN}

Asupan kalsium memiliki hubungan positif yang bermakna dengan kepadatan tulang. Sebaliknya, IMT, massa lemak tubuh dan aktivitas fisik tidak memiliki hubungan yang bermakna dengan kepadatan tulang calcaneus pada wanita dewasa muda.

\section{SARAN}

1. Wanita dewasa muda perlu meningkatkan asupan kalsium untuk mencegah kondisi osteopeni. Asupan kalsium dapat diperoleh pada susu dan hasil susu (keju), ikan dan kacang-kacangan. Tidak dibenarkan mengasup sumber kalsium dari suplemen kalsium.

2. Perlu penelitian lebih lanjut mengenai hubungan antara IMT, komposisi tubuh dan aktivitas fisik dengan kepadatan tulang pada wanita dewasa muda, serta menggunakan DEXA sebagai pengukur kepadatan tulang.

\section{UCAPAN TERIMA KASIH}

Penulis ingin menyampaikan rasa terima kasih kepada responden dan Team Bone Scan Anlene yang telah berperan serta dalam kegiatan penelitian ini.

\section{DAFTAR PUSTAKA}

1. Bess DH. Osteoporosis. In: Maurice ES, Moshe S, A. Catharine R, Benjamin C, Robert JC, editors. 
Modern nutrition in health and disease. $10^{\text {th }}$ ed. Philadelphia: Lippincott William \& Wilkins; 2006. p.1339-49.

2. Balu S. Osteoporosis: Clinical, Radiological, Histological, Assessment and an Experimental Study. New Delhi: Regional Office of the World Health Organisation; 2000.

3. Bambang S. Osteoporosis. In : Sudoyo AW dkk, editors. Buku ajar ilmu penyakit dalam jilid II. $4^{\text {th }}$ ed. Jakarta: Pusat penerbitan Ilmu Penyakit Dalam FK UI; 2006. p.1259-69.

4. G Maalouf, MH Gannage-Yared, J Ezzedine, B Larijani, S Badawi, A Rached, et al. Middle east and north africa consensus on osteoporosis. J Musculoskelet Neuronal Interact [Internet]. 2007 [cited 2012 March 7]; 7:131-43.

5. Ambrish M, Vibha D, Edith L. The Asian Audit: epidemiology, costs and burden of osteoporosis in Asia 2009 [Internet]. 2009 [cited 2012 March 7]. Available from: http://www.iofbonehealth.org.

6. Sarah HG, Theresa NG, Eric DN, David RC, editors. Osteoporosis: clinical guidelines for prevention, diagnosis, and management. New York: Springer Publishing Company; 2008.

7. Departemen Kesehatan RI 2004. Available at http://gizi.depkes.go.id.

8. Heaney RP, Abrams S, Dawson-Hughes B, Looker A, Marcus 5. R, Matkovic V, et al. Peak bone mass. Osteoporos Int 2000; 11 : 985-1009.

9. Anderson JJB. Nutrition and bone health. In: Mahan K, Escott-Stump S, editors. Krause's food, nutrition and diet therapy. $12^{\text {th }}$ edition. Philadelphia: Saunders; 2008. p.614-33.

10. Norman K, Michael Z. Developmental Nutrition. United States: Allyn and Bacon. 1997. p.52,485.

11. Gibson RS. Principle and nutritional assesment. $2^{\text {nd }}$ ed. New York: Oxford University Press; 2005. p.260,366

12. Lane NE. Osteoporosis. $1^{\text {st }}$ ed. Jakarta: PT Raja Grafindo Persada; 2001.

13. Beck TJ, Oreskovic TL, Stone KL. Structural adaptation to changing skeletal load in the progression toward hip fragility: the study of osteoporotic fractures. J bone Miner Res [Internet]. 2001[cited 2012 July 18]; 16: 1108-19. Available from: http://www.jbmr.org.

14. Wardlaw GM. Putting body weight and osteoporosis into perspective. Am J Clin Nutr [Internet]. 1996 [cited 2012 March 7]; 63:433S436S. Available from: http://www.ajcn.org.

15. Mary BL, Justine S, Brenda AW, Andrew MT, Babette SZ. Obesity during childhood and adolescence augments bone mass and bone dimensions. Am J Clin Nutr [Internet]. 2004 [cited 2012 March 7]; 80:514-23. Available from: http://www.ajcn.org.

16. Yoko M, Yoshiko O, Akiko H, Tatsuhiko K, Satoshi S, Hiroaki O. Effect of physical activity and nutrition on bone mineral density in young
Japanese women. J Bone Miner Metab [Internet]. 2007 [cited 2012 July 18]; 25:414-418. Available from: http://www.jbmr.org.

17. Fatima $M$ et al. Determining the risk factor and prevalence of osteoporosis using quantitative ultrasonography in Pakistani adult women. Singapore Med J [Internet]. 2009 [cited 2012 March 7]; 50 (1):20-8.

18. Nur FF. Hubungan komposisi tubuh dengan bone mass density (BMD) pada pasien rawat jalan di RS. Dr. Sardjito Yogyakarta [skripsi]. Semarang: Universitas Diponegoro; 2008.

19. Albala C, Yanez M, Devoto E, Sostin C, Zeballos L, Santos JL.Obesity as a protective factor for postmenopausal osteoporosis. Int $\mathrm{J}$ Obes Relat Metab Disord [Internet]. 1996 [cited 2012 March 7]; 20:1027-32.

20. P Ravn et al. Low Body Mass Index Is an Important Risk Factor for Low Bone Mass and Increased Bone Loss in Early Postmenopausal Women. J Bone Miner Res [Internet]. 1999 [cited 2012 March 7]; 14:1622-27. Available from: http://www.jbmr.org.

21. Yi-Hsiang $\mathrm{H}$ et al. Relation of body composition, fat mass, and serum lipids to osteoporotic fractures and bone mineral density in Chinese men and women. Am J Clin Nutr [Internet]. 2006 [cited 2012 March 7]; 83:146-54. Available from: http://www.ajcn.org.

22. Lan-Juan Zhao, Yong-Jun Liu, Peng-Yuan Liu, James Hamilton, Robert R. Recker, and HongWen Deng. Relationship of obesity with osteoporosis. J Clin Endocrinol Metab [Internet]. 2007 [cited 2012 March 7]; 92: 1640-1646.

23. Norman KP, Emma ML, Clifton AB, Mark WH, Daniel BH dan Richard DL. Is adiposity advantageous for bone strength? a peripheral quantitative computed tomography study in late adolescent females. Am J Clin Nutr [Internet]. 2007 [cited 2012 March 7]; 86:1530-8. Available from: http://www.ajcn.org.

24. AA Usfar, E Lebenthal, Atmarita, E Achadi, Soekirman, H Hadi. Obesity as a poverty-related emerging nutrition problems: the case of Indonesia. Obesity reviews [Internet]. 2010 [cited 2012 March 7]; 11:924-928.

25. Badan Penelitian dan Pengembangan Kesehatan Departemen Kesehatan RI. Riskesdas tahun 2007.

26. Sakamoto $\mathrm{Y}$ et al. comparison of the WHO BMIclassification and body composition in ethnic group difference. $24^{\text {th }}$ Japan Society for the study of obesity [Internet]. 2003 [cited 2012 March 20].

27. Vivian HH, Lisa MS. Applied body composition assessment. New York: Human Kinetics; 1996. p.5.

28. Widajanti L. Buku petunjuk praktikum survei konsumsi gizi. Semarang: Bagian Prodi Magister Gizi Masyarakat Program Pascasarjana UNDIP. 2007. 
29. Departemen Kesehatan RI. Angka kecukupan gizi 2004 bagi orang Indonesia. Available at http://gizi.depkes.go.id/download/AKG2004.pdf.

30. IPAQ. Guidelines for Data Processing and Analysis of the International Physical Activity Questionnaire (IPAQ). 2005.

31. I Dewa NS, Bachyar B, Ibnu F. Penilaian Status Gizi. Jakarta: EGC. 2001. p.58-60,98-101,191208.

32. MC Wang, LK Bachrach, MV Loan, M Hudes, KM Flegal, PB Crawford. The relative contributions of lean tissue mass and fat mass to bone density in young women. Bone 37 [Internet]. 2005 [cited 2012 July 18]; 474-481.

33. Reid IR, Legge M, Stapleton JP, Evans MC, Grey AB 1995 Regular exercise dissociates fat mass and bone density in premenopausal women. J Clin Endocrinol Metab 80:1764-1768.

34. ZemelMB2004 Role of calcium and dairy products in energy partitioning and weight management. Am J Clin Nutr 79:907S-912S.

35. E Rautava et al. the reduction of physical activity reflects on the bone mass among young females: a follow-up study of 142 adolescent girls. Osteoporosis Int [Internet]. 2007 [cited 2012 July 18]; 18:915-922.
36. Raman K. Marwaha, Seema Puri, Nikhil Tandon, Sakshi Dhir, Neha Agarwal, Kuntal Bhadra, et al. Effects of sports training \& nutrition on bone mineral density in young Indian healthy females. Indian J Med Res 134, September 2011, pp 307313.

37. JN Farr, RM Blew, VR Lee, TG Lohman, SB Going. Associations of physical activity duration, frequency, and load with volumetric BMD, geometry, and bone strength in young girls. Osteoporos Int. DOI 10.1007/s00198-010-1361-8.

38. Sunita A. Prinsip dasar ilmu gizi. Jakarta: Gramedia Pustaka Utama; 2010. p.243.

39. Sahara: waterless ultrasound bone densitometry for the office-based physician [Internet]. [updated ; cited 2012 May 13]. Available from:http://www.hologic.com.

40. About bone densitometry [Internet]. [updated ; cited 2012 May 13]. Available from: http://www.BoneDensitometers.com.

41. Gabriela TM, Rubén GP, Martha MT, Eduardo LP. Peak bone mass and bone mineral density correlates for 9 to 24 year-old Mexican women, using corrected BMD. Salud Publica Mex 2009;51 suppl 1:S84-S92. 